
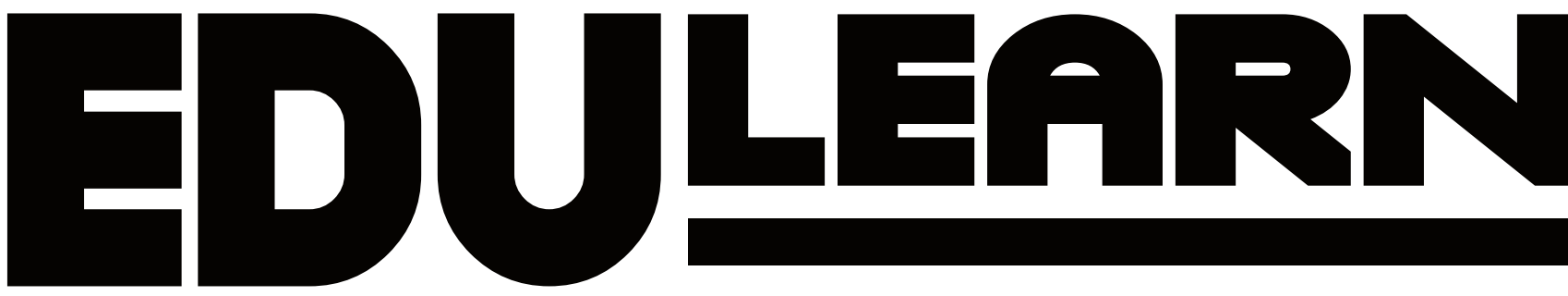

16

8TH INTERNATIONAL CONFERENCE ON EDUCATION AND NEW LEARNING TECHNOLOGIES
BARCELONA (SPAIN) 4TH - 6TH OF JULY, 2016
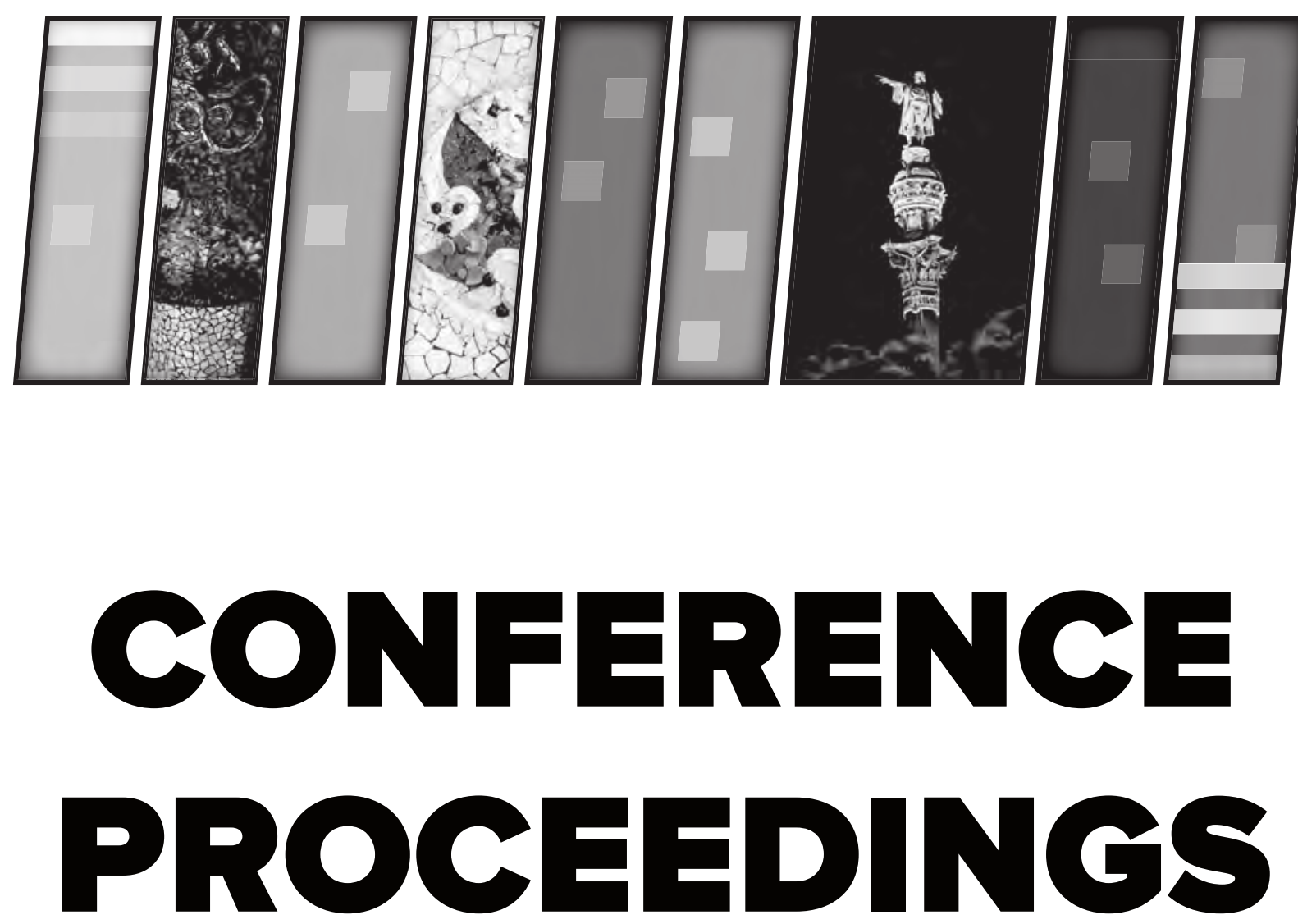
Published by

IATED Academy

iated.org

\section{EDULEARN16 Proceedings}

8th International Conference on Education and New Learning Technologies July 4th-6th, 2016 - Barcelona, Spain

\section{Edited by}

L. Gómez Chova, A. López Martínez, I. Candel Torres

IATED Academy

ISBN: 978-84-608-8860-4

ISSN: 2340-1117

Depósito Legal: V-1421-2016

Book cover designed by

J.L. Bernat

All rights reserved. Copyright (C) 2016, IATED

The papers published in these proceedings reflect the views only of the authors. The publisher cannot be held responsible for the validity or use of the information therein contained. 


\title{
PLAYGROUNDS GOING WRONG: STUDY OF THE ADULT STYLE AND CHILDREN'S RIGHTS DURING RECESS IN AN EARLY CHILDHOOD AND PRIMARY EDUCATION CENTER
}

\author{
Maria P. Figueiredo ${ }^{12}$, Francisca Santos ${ }^{1}$ \\ ${ }^{1}$ School of Education, Polytechnic of Viseu (PORTUGAL) \\ ${ }^{2}$ CI\&DETS, Polytechnic of Viseu (PORTUGAL)
}

\begin{abstract}
Recent perspectives on Pedagogy for Early Childhood Education emphasize children's participation in line with the Children's Rights Convention. The study aimed to analyse how children's rights are dealt with during recess in a school (Early Childhood and Primary Education) in Portugal. The aims were: to characterize the style of the adult (teaching assistants) and the interactions that are established with the children at the playground/recess, and analyse them in terms of children's rights. The qualitative approach was based on the observation during the recess for three weeks. The Adult Style Observation Schedule for Early Childhood Education (ASOS-ECE) was used to register and code the dynamics of six teaching assistants ( $3 \mathrm{ECE}$ and $3 \mathrm{PE}$ ). Critical incidents were also registered. Statistical analysis of the ASOS-ECE levels were complemented with the content analysis of the notes. The playground space was quite limited and affected children's play and well-being. The outdoor playground was never used for the Early Childhood classes, only for Primary Education students but with little supervision. Children were often deprived of playground time by decision of the teaching assistants, as punishment. The results obtained through the Adult Style Observation Schedule for Early Childhood Education (ASOS-ECE) are not satisfactory and are below what would meet the minimum quality value $(3,5)$. For Early Childhood Education, sensibility is the most valued dimension but with very low levels $(<2,5)$. For Primary Education it was autonomy that scored highest $(<2,5)$. The analysis of the notes/critical incidents highlighted articles 12 (expression of own views), 13 (freedom of expression), 19 (protection against violence), 29 (development of personality) and 31 (rest and leisure, play and recreational activities) as being put into question by actions of the adults responsible for the children. Children's rights and well-being need to be put forward in the knowledge base for all adults working with children so that Pedagogy can fulfil its purpose fully.
\end{abstract}

Keywords: Early childhood education, primary education, children's rights, adult style, playground.

\section{EARLY CHILDHOOD PEDAGOGY AND CHILDREN'S RIGHTS}

According to the Convention on the Rights of the Child [1] children are all those who are under eighteen. In other contexts, other definitions are considered. For example, in the book about human development, Papalia, Olds and Feldman [2] consider that the onset of adolescence, when childhood ends, is located approximately from 11 or 12 to 14 years old. Regardless of the age limit, other dimensions of childhood influence different ways of conceiving this period of life. Until the last two decades of the twentieth century, the Western world conceived children from two different points of view, on the one hand, to be in danger, associated with dependency, vulnerability and naivety, and, on the other hand, as dangerous both for themselves and the global society. However, these ideas have been changed due to the following: the decrease in the birth rate in industrialized countries, the growing diversity in the circumstances of life of children, multiple socialization of children thanks to growing transnational flows of people, goods, values and images, increasing efforts to guide children and the incidence of voice children's rights [3]. Finally, "The sociological discipline known to the New Sociology of Childhood offers a framework Within Which childhood is positioned as a distinct period of life and interest; children's lives the experience Them They are now the focus; and research methods are adapted to suit children's unique strengths and needs" [4]. The coexistence and interaction between the various childhood conceptions allows us to state that there is not "a childhood", but various childhood images, which are socially interpreted and reconstructed within the groups and social processes that generate them. In this process, the school institution, and child care institutions, are noteworthy for their influence, both on children or on the way society perspective children [5].

Taking into account a more contemporary perspective, the child is considered as co-constructor of knowledge, identity and culture. She is an active participant, having a voice of her own that should be 
taken into account both at the democratic level and in decision-making [6]. Children's Rights play a considerable role in shaping the way we think about childhood, or "plurality of childhoods" [5].

The role of children in society, today, also marks a new approach: "... children and young people as essential social agents and participating in society, implying not only the formal recognition of rights but also the conditions of their exercise through a full and real role in all spheres of social life" [7]. Coupled with this change in relation to how the child participates in social processes, are two principles: belief in the rights of children and the belief in the competences of children, with the first principle related to the right of the child to be heard, right to participate and have control over her life and the second principle related to the belief in the competence of the child to understand, reflect, give consistent answers and participate actively in social life [8]. Several reasons are advanced to listen to children, or consider their opinions and input in decisions concerning them. In addition to the rights guaranteed by the Convention on the Rights of the Child, it is considered that listening enhances the possibility that the decisions taken are relevant and appropriate. So to be heard about issues that concern them is a right of children (not a concession we make them) and this can help adults make better decisions.

Recent perspectives on Pedagogy for Early Childhood Education emphasize children's participation [9]-[12] in line with the Children's Rights Convention [1]. How the right to "freely express their views on issues that concern them and to have that view taken into account" is substantiated in teaching practices is still a challenge [13], [14], even when acknowledged as a pedagogical principle in the curriculum guidelines, like in the Portuguese case [15]. It is important to look not only at the teaching but at the whole experience of being in the school as a educational institution. Several authors highlight that the daily interactions of adults with children are crucial to the implementation of children's rights [16], [17] and to their well-being and learning. During the day, children interact with teachers but also with teaching assistants that are responsible for several parts of their daily experience, mainly meals, hygiene and recess.

\section{METHODOLOGY}

The study aimed to analyse how children's rights are dealt with during recess in a school (Early Childhood and Primary Education) in Portugal. The aims were: to characterize the style of the adult (teaching assistants) and the interactions that are established with the children at the playground/recess, and analyse them in terms of children's rights. The qualitative approach was based on the observation during the recess for three weeks.

The study was conducted as a covert investigation, using the concept of Bogdan and Biklan [18] to describe a collection of data without the express consent of the subjects. Since it was intended to observe the action of teaching assistants in the recess, it was considered that informing them of this observation would alter the interactions. Thus, it was decided not to clarify the object of observations, although everyone was informed that a study was being conducted on the playground, but that children were the target.

The Adult Style Observation Schedule for Early Childhood Education (ASOS-ECE) [19] was used to register and code the dynamics of six teaching assistants ( 3 connected to early childhood groups and 3 connected to primary education classes). Critical incidents were also registered. Statistical analysis of the ASOS-ECE levels were complemented with the content analysis of the notes.

\section{RESULTS}

The playground space was quite limited and affected children's play and well-being. The outdoor playground was never used for the Early Childhood groups, only for Primary Education students but with little supervision. Children were often deprived of playground time by decision of the teaching assistants, as punishment.

The results obtained through the Adult Style Observation Schedule for Early Childhood Education (ASOS-ECE) are not satisfactory and are below what would meet the minimum quality value $(3,5)$.

After the observations and analysis of the scale for six sessions/days, the following results were obtained for Early Childhood Education. 
Table 1: Average per dimension of the Adult Style Observation Schedule for all sessions in ECE

\begin{tabular}{|c|c|c|c|c|c|c|c|}
\hline \multirow[b]{2}{*}{ dimensions } & \multicolumn{6}{|c|}{ session } & \multirow[b]{2}{*}{ average } \\
\hline & 1 & 2 & 3 & 4 & 5 & 6 & \\
\hline sensibility & 3 & 2,3 & 1,6 & 2,2 & 2,1 & 1,6 & 2,1 \\
\hline stimulation & 2,6 & 1,8 & 1,2 & 2,3 & 1,2 & 1,2 & 1,8 \\
\hline autonomy & 2,4 & 1,6 & 1,2 & 1,5 & 1,8 & 2,2 & 1,8 \\
\hline average & 2,7 & 1,9 & 1,3 & 2 & 1,7 & 1,7 & \\
\hline
\end{tabular}

In ECE (Tabble 1), there isn't one single session on which the average of records made reaches the minimum level of quality $(3,5)$. For Early Childhood Education, sensibility is the most valued dimension but with very low levels $(<2,3)$. This higher value of sensibility is coherent with other studies in Portugal that show that this is the stronger dimension of Portuguese ECE professionals [20].

Table 2: Average per dimension of the Adult Style Observation Schedule for all sessions in PE

\begin{tabular}{|c|c|c|c|c|c|c|}
\hline & \multicolumn{5}{|c|}{ session } & \\
\hline dimensions & $\mathbf{1}$ & $\mathbf{2}$ & $\mathbf{3}$ & $\mathbf{4}$ & $\mathbf{5}$ & average \\
\hline sensibility & 2,2 & 2,2 & 2 & 1,6 & 2,6 & 2,1 \\
\hline stimulation & 2 & 1,6 & 2 & 1,1 & 2 & 1,7 \\
\hline autonomy & 3 & 2,6 & 2 & 2,1 & 2 & 2,3 \\
\hline average & 2,4 & 2,1 & 2 & 1,6 & 2,2 & \\
\hline
\end{tabular}

For Primary Education (Table 2) it was autonomy that scored highest $(<2,5)$. Again, all averages are below the desired 3,5. Higher levels of autonomy, compared with ECE, refer to adults allowing more space for children to decide what to do - but with no real autonomy.

The analysis of the notes/critical incidents highlighted articles 12 (expression of own views), 13 (freedom of expression), 19 (protection against violence), 29 (development of personality) and 31 (rest and leisure, play and recreational activities) as being put into question the most by actions of the adults responsible for the children.

\section{CONCLUDING IDEAS}

If pedagogy is constituted by "informed interpretations of learners, knowledge and environments in order to manipulate environments in ways that help learners make sense of the knowledge available to them. It is an intense, complex and discursive act, which demands considerable expertise" [21], children's rights and well-being have to be put forward in the knowledge base for all adults working with children. After the study, the authors developed workshops for the teaching assistants of the study in terms of Children's Rights and Outdoor Education.

\section{REFERENCES}

[1] Organização das Nações Unidas, "Convenção sobre os Direitos da Criança." Organização das Nações Unidas, 1989.

[2] D. E. Papalia, S. W. Olds, and R. D. Feldman, Human development, 11th ed. Nova lorque: McGraw-Hill, 2009.

[3] A. Prout, The Future of Childhood. Londres: Routledge, 2004.

[4] W. A. Corsaro, The Sociology of Childhood, 2nd ed. Thousand Oaks: SAGE Publications, 2005.

[5] A. Coelho, "Repensar o campo da Educação da Infância," Rev. Iberoam. Educ., vol. 44, no. 3, 2007.

[6] G. Dahlberg, P. Moss, and A. Pence, Qualidade na educação da primeira infância. Perspectivas pós-modernas. Porto Alegre: Artmed Editora, 2003. 
[7] M. Sarmento, N. F. Soares, and C. Tomás, "Participação social e cidadania ativa das crianças," in Inclusão e Educação. Doze Olhares sobre a Educação Inclusiva, D. Rodrigues, Ed. São Paulo: Summus Editorial, 2006, pp. 141-159.

[8] J. Oliveira-Formosinho and S. Araújo, "Escutar as vozes das crianças como meio de (re)construção de conhecimento acerca da infância: algumas implicações metodológicas," in $A$ escola vista pelas crianças, J. Oliveira-Formosinho, Ed. Porto: Porto Editora, 2008, pp. 11-29.

[9] C. Rinaldi, "The Reggio Emilia Approach - Truly listening to young children," in Five curriculum outlines. Curricula and Pedagogies in Early Childhood Education and Care, OECD Directorate for Education, Ed. Paris: OECD, 2004, pp. 12-15.

[10] T. Vasconcelos, A Educação de Infância no cruzamento de fronteiras. Lisboa: Texto Editora, 2009.

[11] J. Oliveira-Formosinho, "Pedagogia(s) da infância: reconstruindo uma práxis de participação," in Pedadagogia(s) da Infância. Dialogando com o passado, construindo o futuro, J. OliveiraFormosinho, T. Kishimoto, and M. Pinazza, Eds. São Paulo: Artmed Editora, 2007, pp. 13-36.

[12] M. P. Figueiredo, "Práticas de produção de conhecimento: a investigação na formação inicial de educadores de infância," Tese de Doutoramento em Educação, especialidade em Didática e Desenvolvimento Curricular, Universidade de Aveiro, Aveiro, 2013.

[13] C. Tomás, "Há muitos mundos no mundo": cosmopolitismo, participação e direitos da criança. Porto: Ed. Afrontamento, 2011.

[14] K. A. Agostinho, "Formas de participação das crianças na educação infantil," Tese de Doutoramento em Sociologia da Infância, Universidade do Minho, Braga, 2010.

[15] Ministério da Educação, Orientações curriculares para a educação pré-escolar. Lisboa: Ministério da Educação, 1997.

[16] D. Maleš and Z. Gunc, "Viver e aprender os Direitos das crianças: do nível nacional ao local da Croácia," Infânc. Na Eur., vol. 17, pp. 21-23, 2009.

[17] G. Portugal and F. Laevers, Avaliação em Educação Pré-Escolar - Sistema de Acompanhamento das Crianças. Porto: Porto Editora, 2010.

[18] R. Bogdan and S. Biklen, Investigação qualitativa em educação: uma introdução à teoria e aos métodos. Porto: Porto Editora, 1994.

[19] F. Laevers, Adult Style Observation Schedule for Early Childhood Education (ASOS-ECE). Lovaina: Centre for Experiential Education, 1994.

[20] B. Direito, "Prática de ensino supervisionada e trabalho de investigação: um percurso formativo centrado nas interações," Relatório Final de Estágio do Mestrado em Educação Pré-Escolar e Ensino do 1. ${ }^{\circ}$ Ciclo do Ensino Básico, Escola Superior de Educação de Viseu, Instituto Politécnico de Viseu, Viseu, 2012.

[21] A. Edwards, "Researching pedagogy: a sociocultural agenda," Pedagogy Cult. Soc., vol. 9, no. 2, pp. 161-186, 2001. 